\title{
Adiposity and hand osteoarthritis: the Netherlands Epidemiology of Obesity study
}

\author{
A Willemien Visser ${ }^{1 *}$, Andreea loan-Facsinay ${ }^{1}$, Renée de Mutsert ${ }^{2}$, Ralph L Widya ${ }^{3}$, Marieke Loef ${ }^{1}$, Albert de Roos ${ }^{3}$, \\ Saskia le Cessie ${ }^{2}$, Martin den Heijer ${ }^{2,4}$, Frits R Rosendaal ${ }^{2}$, Margreet Kloppenburg ${ }^{1,2}$ for the NEO Study Group
}

\begin{abstract}
Introduction: Obesity, usually characterized by the body mass index (BMI), is a risk factor for hand osteoarthritis (OA). We investigated whether adipose tissue and abdominal fat distribution are associated with hand OA.

Methods: The Netherlands Epidemiology of Obesity (NEO) study is a population-based cohort aged 45 to 65 years, including 5315 participants (53\% women, median BMI $29.9 \mathrm{~kg} / \mathrm{m}^{2}$ ). Fat percentage and fat mass (FM) (kg) were estimated using bioelectrical impedance analysis. The waist-to-hip ratio (WHR) was calculated. In 1721 participants, visceral adipose tissue (VAT) and subcutaneous adipose tissue (SAT) $\left(\mathrm{cm}^{2}\right)$ were assessed using abdominal MR imaging. Hand OA was defined according to the ACR criteria.

Odds ratios (OR) with 95\% confidence intervals (Cl) were calculated for the association of fat percentage, FM, WHR, VAT and SAT with hand OA using logistic regression analyses per standard deviation, stratified by sex and adjusted for age.

Results: Hand OA was present in $8 \%$ of men and $20 \%$ of women. Fat percentage was associated with hand OA in men (OR 1.34 (95\% Cl 1.11 to 1.61)) and women (OR 1.26 (1.05 to 1.51)), as was FM. WHR was associated with hand OA in men (OR 1.45 (1.13 to 1.85)), and to a lesser extent in women (OR 1.17 (1.00 to 1.36)). Subgroup analysis revealed that VAT was associated with hand OA in men (OR1.33 (1.01 to 1.75)). This association increased after additional adjustment for FM (OR 1.51 (1.13 to 2.03)).
\end{abstract}

Conclusions: Fat percentage, FM and WHR were associated with hand OA. VAT was associated with hand OA in men, suggesting involvement of visceral fat in hand OA.

\section{Introduction}

Osteoarthritis (OA) is the most common musculoskeletal disorder. Although the pathogenesis of OA remains largely unknown, several risk factors are known to contribute to disease development. One of the most prominent risk factors is overweight or obesity, usually defined by body mass index (BMI) of 25 to $30 \mathrm{~kg} / \mathrm{m}^{2}$ or $\geq 30 \mathrm{~kg} / \mathrm{m}^{2}$, respectively [1]. Obesity acts as a risk factor for both weight-bearing joints and nonweight-bearing joints, suggesting that obesity-associated systemic factors could play an important role in OA $[2,3]$. The relative contribution of systemic factors and excessive biomechanical stress in the association between obesity and $\mathrm{OA}$ remains to be

\footnotetext{
* Correspondence: a.w.visser@lumc.nl

'Department of Rheumatology, C1-R, Leiden University Medical Center, P.O. Box 9600, 2300 RC, Leiden, the Netherlands

Full list of author information is available at the end of the article
}

elucidated and could be different for different subtypes of $\mathrm{OA}$, such as hand OA versus knee OA.

Although the systemic effects of obesity are most probably dependent on the amount and distribution of adipose tissue, most studies on OA performed until now used BMI as marker for obesity. However, since BMI is defined based only on height and weight, it provides little information about body composition and the amount and distribution of adipose tissue. More insight into the relation between adiposity and OA can be obtained when alternative measures of body composition are investigated, such as the fat percentage, fat mass (FM) and waist-to-hip ratio (WHR). Previous research assessing these body composition measures mostly studied knee OA and showed inconclusive results regarding FM [4-9], whereas WHR was not associated with OA $[4,7,10]$. Only a few studies focused on $\mathrm{OA}$ in nonweight-bearing joints such as the hands, showing no association with fat percentage and

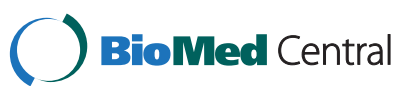


waist circumference and conflicting results regarding the WHR $[8,11-13]$.

Adipose tissue is a source of several cytokines that could influence whole-body metabolism. Secretion of these bioactive mediators depends on the type of adipose tissue; they are secreted more actively by visceral fat than by subcutaneous fat [14]. In addition, visceral fat has been shown to be associated more strongly with obesity-related comorbidities, such as diabetes mellitus and the metabolic syndrome, and with markers of inflammation as compared with subcutaneous fat $[15,16]$. Cytokines have the potential to affect joint tissues [17-19], and therefore visceral fat could also be involved in the pathogenesis of OA. No research has so far been performed regarding different body fat depots in relation to OA.

The aim of the present study was to gain more insight into the mechanisms underlying the association of adiposity and OA. To this end, we investigated the association of adipose tissue and its abdominal distribution with the presence of $\mathrm{OA}$ in nonweight-bearing joints, the hands.

\section{Methods}

\section{Study design and study population}

The Netherlands Epidemiology of Obesity (NEO) study is a population-based prospective cohort study in lean, overweight and obese individuals aged between 45 and 65 years. The present study is a cross-sectional analysis of the baseline measurements of the 5,313 participants included in the NEO study between September 2008 and January 2012. Detailed information about the study design and data collection has been described previously [20]. Men and women with self-reported BMI $\geq 27$ $\mathrm{kg} / \mathrm{m}^{2}$ living in the greater area of Leiden (in the west of the Netherlands) were eligible to participate in the NEO study. In addition, in one municipality (Leiderdorp) all inhabitants aged 45 to 65 years were invited, irrespective of their BMI. All participants completed questionnaires on demographic and clinical data and visited the NEO study center for several baseline measurements. The study was approved by the medical ethics committee of the Leiden University Medical Center and all participants gave written informed consent.

\section{Body composition measures}

Measured body weight $(\mathrm{kg})$ and height $(\mathrm{cm})$ were used to calculate the BMI $\left(\mathrm{kg} / \mathrm{m}^{2}\right)$. Waist and hip circumference $(\mathrm{cm})$ were used to calculate the WHR. The percentage of body fat and amount of FM $(\mathrm{kg})$ were measured by bioelectrical impedance analysis (BIA) using the Tanita footto-foot BIA system TBF-300A Body Composition Analyzer (Tanita Corporation of America, Inc, Arlington Heights, IL, USA) [21]. To test the reliability, repeated measurements were performed after approximately 3 months in a random sample of 72 participants; the calculated intraclass correlation coefficient was 0.98 .

\section{Abdominal adipose tissue}

A random sample (about 30\%) of the study participants without contraindications (metallic devices, claustrophobia and a body circumference $\geq 170 \mathrm{~cm}$ ) underwent magnetic resonance imaging (MRI) of the abdomen. Abdominal visceral adipose tissue (VAT) and subcutaneous adipose tissue (SAT) $\left(\mathrm{cm}^{2}\right)$ were measured by a turbo spin echo imaging protocol, performed on a $1.5 \mathrm{~T}$ system (Philips, Medical Systems, Best, the Netherlands): echo time, 11 milliseconds; repetition time, 168 milliseconds; flip angle, $90^{\circ}$; slice thickness, $10 \mathrm{~mm}$. The total acquisition time, including the initial survey sequence, was 3 minutes. At the level of the fifth lumbar vertebra, three transverse images with a slice thickness of $10 \mathrm{~mm}$ were obtained during a breath-hold. The MASS software package (Medis, Leiden, the Netherlands) was used to quantify VAT and SAT, allowing a semiautomated detection of the VAT and SAT area. The mean values of VAT and SAT $\left(\mathrm{cm}^{2}\right)$ were calculated.

\section{Osteoarthritis definition}

Self-reported pain was measured using standardized questionnaires. Physical examination of the hand joints was performed by trained research nurses, using a standardized scoring form. Bony and soft swellings of the distal interphalangeal (DIP), proximal interphalangeal (PIP), metacarpophalangeal (MCP), carpometacarpal (CMC) and wrist joints were scored, as well as deformities of the DIP, proximal interphalangeal (PIP), first metacarpophalangeal (MCP), carpometacarpal (CMC) and wrist joints. OA was defined according to the criteria of the American College of Rheumatology as pain or stiffness on most days of the prior month in addition to three of the following criteria: bony swelling of $\geq 2$ of the 10 selected joints (bilateral DIP II and III, PIP II and III, and first CMC joints), bony swelling of $\geq 2$ DIP joints, $<3$ swollen MCP joints, and deformity of $\geq 1$ of the 10 selected joints [22].

\section{Statistical analysis}

Data were analyzed using SPSS version 20 (SPSS, Chicago, IL, USA) and STATA version 12 (StataCorp LP, College Station, TX, USA).

In the NEO study there is an oversampling of persons with BMI $\geq 27 \mathrm{~kg} / \mathrm{m}^{2}$. To correctly represent associations in the general population [23], adjustments were made for the oversampling of individuals with BMI $\geq 27 \mathrm{~kg} / \mathrm{m}^{2}$. This was done by weighting individuals towards the BMI distribution of participants from the Leiderdorp municipality [24], whose BMI distribution was similar to the BMI distribution in the general Dutch population [25]. Consequently, results apply to a population-based study without oversampling of $\mathrm{BMI} \geq 27 \mathrm{~kg} / \mathrm{m}^{2}$. 
Pearson correlation coefficients between all body composition measures were calculated. A correlation below 0.4 was considered weak, between 0.4 and 0.7 moderate, and above 0.7 strong. Logistic regression analyses were used to calculate cross-sectional associations of all body composition measures with hand OA, and were expressed as odds ratios (ORs) with 95\% confidence intervals (CIs). All continuous variables were standardized by dividing individual values by the standard deviation to be able to compare the ORs, because in this way all ORs describe the effect on the odds of OA of an increase of one standard deviation of the corresponding variable. All analyses have been stratified by sex and adjusted for age. To minimize variation in FM due to differences in body height, additional adjustment for height was performed in the analysis on FM. Furthermore, additional adjustment for FM has been performed in the analyses on visceral and subcutaneous fat in relation to hand $\mathrm{OA}$.

\section{Results}

\section{Population characteristics}

After exclusion of subjects with missing data for the BIA $(n=25)$ or physical examination $(n=4)$, data from 5,284 subjects were analyzed. Table 1 presents the baseline characteristics. Median age was 56 years, and 53\% were women. Women had a lower median body weight and WHR but a higher fat percentage and FM than men. Hand OA was present in $8 \%$ of men and $20 \%$ of women.

Abdominal fat was measured in a random subset of 1,721 participants (46\% women). Except for a clinically nonrelevant difference in WHR in men (0.980 vs. 0.982$)$, this subgroup did not differ from the total group (data not shown).
The median amount of VAT was lower than the median amount of SAT, and this difference was most apparent in women (Table 1).

\section{Correlations between body composition measures}

First, we calculated Pearson's correlation coefficients between all measures of body composition (Table 2). Besides body weight, BMI was strongly correlated with fat percentage and FM in both men and women. BMI, body weight, fat percentage and FM were strongly correlated with SAT in both sexes. The correlations of these body composition measures with VAT were somewhat lower, and were slightly stronger in women as compared with men. Moreover, WHR correlated more strongly with VAT than with SAT in both sexes. The WHR showed a stronger correlation with all measurements of fat (FM, SAT and VAT) in men as compared with women.

The differences between men and women underscored the need for stratified analyses in the sexes.

\section{Associations of body composition measures with hand osteoarthritis}

We next investigated the associations of all body composition measures with hand OA (Table 3).

The fat percentage was associated with hand $\mathrm{OA}$ in both men $(\mathrm{OR}=1.34 \quad(95 \% \mathrm{CI}=1.11$ to 1.61$))$ and women $(\mathrm{OR}=1.26(95 \% \mathrm{CI}=1.05$ to 1.51$))$, meaning that one standard deviation increase in fat percentage (men 6.22\%, women 6.88\%) is associated with a $34 \%$ higher risk of having hand OA in men and a $26 \%$ higher risk in women. FM was also associated with hand OA in both sexes (men: $\mathrm{OR}=1.24(95 \% \mathrm{CI}=1.05$ to 1.47$)$; women: $\mathrm{OR}=1.22(95 \% \mathrm{CI}=1.07$ to 1.39$))$. Additional adjustment for height in the analysis

Table 1 Baseline characteristics of the total Netherlands Epidemiology of Obesity study population and stratified by sex

\begin{tabular}{|c|c|c|c|}
\hline & $\begin{array}{l}\text { Total population } \\
(n=5,284)\end{array}$ & $\begin{array}{l}\text { Men } \\
(n=2,490)\end{array}$ & $\begin{array}{l}\text { Women } \\
(n=2,794)\end{array}$ \\
\hline Age (years) & $56(51$ to 61$)$ & $57(51$ to 61$)$ & 56 (51 to 61) \\
\hline $\mathrm{BMI}\left(\mathrm{kg} / \mathrm{m}^{2}\right)$ & 29.9 (27.8 to 32.8$)$ & $29.6(27.9$ to 32.0$))$ & 30.3 (27.8 to 33.5 ) \\
\hline Weight (kg) & 90.6 (80.6 to 100.8$)$ & 96.6 (89.2 to 106.0$)$ & 84.0 (75.8 to 94.2 ) \\
\hline Fat percentage (\%) & 37.5 (29.0 to 43.7) & 29.0 (25.9 to 32.7) & 43.3 (39.9 to 46.4 ) \\
\hline Fat mass (kg) & 32.4 (26.1 to 40.0$)$ & 28.1 (23.6 to 34.0) & 36.4 (30.4 to 43.1$)$ \\
\hline WHR & 0.93 (0.87 to 0.99 ) & 0.98 (0.94 to 1.03$)$ & 0.88 (0.84 to 0.92$)$ \\
\hline $\operatorname{VAT}\left(\mathrm{cm}^{2}\right)^{a}$ & 122.1 (85.4 to 166.3 ) & 142.1 (108.1 to 185.5$)$ & 97.2 (67.8 to 138.2 ) \\
\hline SAT $\left(\mathrm{cm}^{2}\right)^{\mathrm{a}}$ & 308.3 (242.3 to 388.4 ) & 262.4 (210.3 to 324.2$)$ & 359.4 (298.7 to 434.0$)$ \\
\hline Hand osteoarthritis & $746(14.1)$ & $188(7.6)$ & $558(20.0)$ \\
\hline
\end{tabular}

Numbers represent medians (interquartile ranges) or number (percentage).

BMI, body mass index; SAT, subcutaneous adipose tissue; VAT, visceral adipose tissue; WHR, waist-to-hip ratio.

${ }^{a} n=923$ men, $n=798$ women. 
Table 2 Correlations between body composition measures in 2,490 men (right upper corner) and 2,794 women (left lower corner) of the Netherlands Epidemiology of Obesity study

\begin{tabular}{llllllll}
\hline & BMI (kg/m $)$ & Weight $(\mathbf{k g})$ & Fat percentage (\%) & Fat mass $(\mathbf{k g})$ & WHR $^{\mathbf{2}}$ & VAT $^{\mathbf{a}}\left(\mathbf{c m}^{2}\right)$ & SAT $^{\mathbf{a}}\left(\mathbf{c m}^{2}\right)$ \\
\hline BMI $\left(\mathbf{k g} / \mathbf{m}^{2}\right)$ & & 0.864 & 0.859 & 0.920 & 0.608 & 0.667 & 0.802 \\
Weight $(\mathbf{k g})$ & 0.919 & & 0.727 & 0.893 & 0.480 & 0.564 & 0.787 \\
Fat percentage (\%) & 0.871 & 0.890 & & 0.949 & 0.656 & 0.696 & 0.753 \\
Fat mass (kg) & 0.927 & 0.981 & 0.951 & & 0.612 & 0.679 & 0.825 \\
WHR & 0.490 & 0.462 & 0.526 & 0.493 & 0.683 & 0.512 \\
VAT $^{\mathbf{a}}\left(\mathbf{c m}^{2}\right)$ & 0.738 & 0.691 & 0.720 & 0.727 & 0.595 & 0.479 \\
SAT $^{\mathbf{a}}\left(\mathbf{c m}^{2}\right)$ & 0.873 & 0.849 & 0.846 & 0.878 & 0.448 & 0.623
\end{tabular}

All correlations were statistically significant. Numbers represent Pearson correlation coefficients.

BMI, body mass index; SAT, subcutaneous adipose tissue; VAT, visceral adipose tissue; WHR, waist-to-hip ratio.

${ }^{a} n=923$ men, $n=798$ women.

on FM resulted in comparable ORs (men: $\mathrm{OR}=1.29$ (95\% $\mathrm{CI}=1.10$ to 1.51$)$; women: $\mathrm{OR}=1.25(95 \% \mathrm{CI}=$ 1.10 to 1.42$))$.

When focusing on the distribution of adipose tissue, we observed the WHR to be associated with hand OA in men $(\mathrm{OR}=1.45(95 \% \mathrm{CI}=1.13$ to 1.85$))$ and to a lesser extent in women $(\mathrm{OR}=1.17(95 \% \mathrm{CI}=1.00$ to 1.36$)$ ).

\section{Abdominal adipose tissue}

Since both the amount of adipose tissue and its distribution are of importance, we investigated the associations of VAT and SAT with hand OA in a subgroup who underwent MRI of the abdomen (Table 4). No association was observed between SAT and hand OA. VAT, on the other hand, showed a statistically significant association with hand $\mathrm{OA}$ in men $(\mathrm{OR}=1.33(95 \% \mathrm{CI}=1.01$ to 1.75)) but was not associated with hand OA in women.

Since VAT and SAT are associated with the total amount of body fat, we also assessed their association with hand OA independent of total body fat by additional adjustment for FM. As a result, the association of VAT with hand $\mathrm{OA}$ in men increased $(\mathrm{OR}=1.51$ (95\% CI $=1.13$ to 2.03)). In women, again no association between VAT and hand OA was observed $(\mathrm{OR}=0.91(95 \% \mathrm{CI}=0.69$ to 1.20$)$ ).

\section{Discussion}

In this study we aimed to gain insight into the association between adiposity and hand OA. Since both the fat percentage and FM were associated with hand $\mathrm{OA}$ in men and women, the amount of adipose tissue seems to be important. The association between WHR and hand $\mathrm{OA}$ indicates that the fat distribution is also of importance. When assessing the abdominal distribution of adipose tissue, VAT was shown to be associated with hand $\mathrm{OA}$ in men, suggesting involvement of visceral fat in hand OA.

To our knowledge, this study is the first to show an association between the amount of fat and its abdominal distribution with hand OA. Other studies showed associations between $\mathrm{OA}$ of the hands and obesity-related comorbidities: Jonsson and colleagues demonstrated that hand $\mathrm{OA}$ and atherosclerosis were associated in older women; both carotid plaques and coronary calcifications showed a linear association with hand OA severity [26]. Hoeven and colleagues confirmed this observation in a population aged 55 years and older; they showed an association of atherosclerosis and OA of the DIP and MCP joints in women, independent of cardiovascular risk factors [27]. Finally, Haara and colleagues showed that symmetrical DIP OA predicted mortality in women and that $\mathrm{OA}$ in any finger joint predicted cardiovascular mortality

Table 3 Associations of body composition measures and hand osteoarthritis

\begin{tabular}{|c|c|c|c|c|}
\hline & \multicolumn{2}{|c|}{ Standard deviation } & \multicolumn{2}{|c|}{ Adjusted odds ratio $(95 \% \mathrm{Cl})$} \\
\hline & Men & Women & Men $(n=2,490)$ & Women $(n=2,794$ \\
\hline Fat percentage (\%) & 6.22 & 6.88 & $1.34(1.11$ to 1.61$)$ & $1.26(1.05$ to 1.51$)$ \\
\hline Fat mass (kg) & 9.39 & 10.76 & $1.24(1.05$ to 1.47$)$ & $1.22(1.07$ to 1.39$)$ \\
\hline WHR & 0.07 & 0.07 & 1.45 (1.13 to 1.85$)$ & 1.17 (1.00 to 1.36$)$ \\
\hline $\mathrm{BMI}\left(\mathrm{kg} / \mathrm{m}^{2}\right)$ & 4.01 & 5.19 & 1.29 (1.08 to 1.55$)$ & $1.25(1.11$ to 1.41$)$ \\
\hline Weight (kg) & 14.49 & 14.73 & 1.15 (0.92 to 1.45$)$ & $1.20(1.06$ to 1.36$)$ \\
\hline
\end{tabular}

All odds ratios express the increase in odds of osteoarthritis per standard deviation and are adjusted for age.

$\mathrm{BMI}$, body mass index; $\mathrm{Cl}$, confidence interval; WHR, waist-to-hip ratio. 
Table 4 Associations of abdominal adipose tissue and hand osteoarthritis

\begin{tabular}{llllll}
\hline & \multicolumn{2}{c}{ Standard deviation } & & \multicolumn{2}{c}{ Adjusted odds ratio $(\mathbf{9 5 \%} \mathrm{Cl})$} \\
\cline { 2 - 3 } \cline { 5 - 6 } & Men & Women & & Men $(\boldsymbol{n}=\mathbf{9 2 3})$ & Women $(\boldsymbol{n}=\mathbf{7 9 8})$ \\
\hline VAT $\left(\mathrm{cm}^{2}\right)$ & 61.3 & 50.0 & & $1.33(1.01$ to 1.75$)$ & $1.10(0.85$ to 1.44$)$ \\
SAT $\left(\mathrm{cm}^{2}\right)$ & 91.7 & 117.6 & & $1.05(0.74$ to 1.50$)$ & $1.22(0.92$ to 1.63$)$
\end{tabular}

All odds ratios express the increase in odds of osteoarthritis per standard deviation and are adjusted for age.

$\mathrm{Cl}$, confidence interval; SAT, subcutaneous adipose tissue; VAT, visceral adipose tissue.

in men, suggesting an underlying common metabolic factor [28].

A possible common underlying explanation could be an effect of adipose tissue, especially the visceral component. Visceral fat has been shown previously to be associated with coronary calcifications and carotid atherosclerosis $[29,30]$. The amount of visceral fat has also been associated with other obesity-related co-morbidities such as diabetes mellitus and metabolic risk factors such as elevated blood pressure, impaired fasting glucose and elevated triglycerides [15,31,32]. Our study shows that visceral fat is also associated with hand OA, implying that adipose tissue and its products can be involved in hand OA.

Visceral fat has been suggested to secrete bioactive cytokines, acting as a unique pathogenic fat depot [14]. The involvement of visceral fat in the pathogenesis of hand OA might thus be explained by its secretion of cytokines, which have been suggested to act locally in joint tissues [17]. Leptin, known especially for its proinflammatory effect, has been shown to affect human cartilage [17-19]. Adiponectin appears to counteract the effect of leptin by anti-inflammatory actions [17]. In vitro studies suggest that adiponectin affects chondrocyte function and modulates cartilage destruction, which might indicate a protective role for adiponectin in OA [33]. This suggestion has been confirmed in an observational follow-up study in patients with hand OA, showing that a higher level of adiponectin is associated with a lower risk for hand OA progression [34]. Knowledge on other adipose-derived cytokines in relation to $\mathrm{OA}$ is scarce.

Differences between both sexes regarding body compositions are well known and were also observed in this study. Women had a lower WHR, more subcutaneous fat and less visceral fat than men. The WHR was more strongly correlated to all measurements of fat in men than in women. This is in accordance with previous studies describing sex differences in body composition measures $[35,36]$. Because of these differences between men and women regarding most body composition measures, all analyses were stratified by sex.

The greater amount of overall fat and lower susceptibility to accumulate visceral fat in women as compared with men might explain the lower ORs of WHR and VAT for hand OA in women. A similar gender difference regarding VAT has been described previously in a study on cardiometabolic risk; VAT was observed to be of greater relevance in men, whereas total FM was of most importance in women [37]. In addition, VAT was observed to be associated with insulin resistance and inflammatory markers primarily in men [38,39]. Another explanation for the lower ORs of WHR and VAT in women might be the importance of unmeasured or unknown risk factors such as hormonal status or genetic effects, overshadowing a possible relatively minor effect of visceral fat.

There are some potential limitations of this study. Hand OA could only be diagnosed based on clinical criteria since no imaging data of the hands were available. However, the ACR clinical criteria are well validated and have a high sensitivity and specificity in diagnosing hand OA [22].

Furthermore, the fat percentage and FM were measured using a foot-to-foot BIA system, and not with a hand-tofoot BIA. Although it has been suggested that foot-to-foot BIA might overestimate the amount of FM [40], a study comparing body fat percentages provided by foot-to-foot BIA with those obtained by hand-to-foot BIA observed a strong correlation between the two methods $(r=0.84)$ [21]. In a study comparing resistance measurements obtained from foot-to-foot BIA with those from underwater weighing and dual-energy X-ray absorptiometry, a strong correlation $(r=0.89)$ with both methods was also reported [41].

We investigated all body composition measures in relation to hand OA per standard deviation to be able to compare the different ORs observed in this study. However, whereas the fat percentage and FM involve whole body fat, the amounts of VAT and SAT apply to a small region of the abdominal fat depot. The ORs for fat percentage and FM therefore cannot be compared directly with the ORs for VAT and SAT.

The amount of VAT and SAT were measured in a random $30 \%$ of the total study population. Although individuals with a body circumference of $170 \mathrm{~cm}$ or higher were not eligible for MRI, body composition measures of the MRI subgroup were not significantly different as compared with the total study population. However, since individuals with extremely high body circumference could not be assessed, the described association between VAT and hand OA might be underestimated.

\section{Conclusion}

This study showed that both the amount of adipose tissue and its distribution are of importance in hand OA. Assessment of the abdominal distribution of adipose tissue showed an association between VAT and hand OA in men, suggesting involvement of visceral fat in hand OA. More research is necessary to gain more insight into the role of adipose tissue in OA, aiming at abdominal fat distribution and secretion of cytokines in relation to OA. 
Longitudinal studies could help to better understand how visceral fat plays a role in OA development. Furthermore, research towards treatment aiming at the inflammatory effect of adipose tissue may lead to potential new treatment targets in OA.

\section{Abbreviations}

BIA: bioelectrical impedance analysis; BMI: body mass index; Cl: confidence interval; CMC: carpometacarpal; DIP: distal interphalangeal; FM: fat mass; MCP: metacarpophalangeal; MRI: magnetic resonance imaging;

NEO: Netherlands Epidemiology of Obesity; OA: osteoarthritis; OR: odds ratio; PIP: proximal interphalangeal; SAT: subcutaneous adipose tissue; VAT: visceral adipose tissue; WHR: waist-to-hip ratio

\section{Competing interests}

The authors declare that they have no competing interests.

\section{Authors' contributions}

AWV performed the statistical analysis, interpreted the data and drafted the manuscript. RLW and ML contributed to the acquisition of the data. Al-F, RdM, AdR, SIC, MdH and FRR participated in the study design. Al-F, RdM, RLW, ML, AdR, SIC, MdH and FRR revised the manuscript for important intellectual content. MK participated in the study design, was involved in analyzing and interpreting the data, and was involved in drafting and revising the manuscript. All authors read and approved the final version of the manuscript.

\section{Acknowledgements}

The authors express their gratitude to all individuals who participate in the NEO study. They are grateful to all participating general practitioners for inviting eligible participants. The authors furthermore thank all research nurses for collection the data and I de Jonge, MSc for all data management in the NEO study.

The NEO study is supported by the Dutch Arthritis Foundation, the participating departments, the Division and the Board of Directors of the Leiden University Medical Center, and the Leiden University, Research Profile Area 'Vascular and Regenerative Medicine'.

NEO Study Group: Frits R Rosendaal, Renée de Mutsert, Ton J Rabelink, Johannes WA Smit, J Wouter Jukema, Albert de Roos, Saskia le Cessie, Pieter S Hiemstra, Margreet Kloppenburg, Tom WJ Huizinga, Hanno Pijl, Eelco JP de Koning, Willem JJ Assendelft, Pieter H Reitsma, Ko Willems van Dijk, Aiko PJ de Vries, Hildo J Lamb, Ingrid M Jazet, Olaf M Dekkers, Nienke R Biermasz, Jeanet W Blom (Leiden University Medical Center, Leiden, the Netherlands), Martin den Heijer, Jacqueline M Dekker and Brenda W Penninx (VU University Medical Center, Amsterdam, the Netherlands).

\section{Author details}

'Department of Rheumatology, C1-R, Leiden University Medical Center, P.O. Box 9600, 2300 RC, Leiden, the Netherlands. ${ }^{2}$ Department of Clinical Epidemiology, C7-P, Leiden University Medical Center, Box 9600, 2300 RC, Leiden, the Netherlands. ${ }^{3}$ Department of Radiology, C2-S, Leiden University Medical Center, P.O. Box 9600, 2300 RC, Leiden, the Netherlands. ${ }^{4}$ Department of Endocrinology, Vrije Universiteit Medical Center, P.O. Box 7057, 1007 MB, Amsterdam, the Netherlands.

Received: 31 July 2013 Accepted: 10 January 2014

Published: 22 January 2014

\section{References}

1. Anderson JJ, Felson DT: Factors associated with osteoarthritis of the knee in the first national Health and Nutrition Examination Survey (HANES I). Evidence for an association with overweight, race, and physical demands of work. Am J Epidemiol 1988, 128:179-189.

2. Yusuf E, Nelissen RG, loan-Facsinay A, Stojanovic-Susulic V, DeGroot J, van OG, Middeldorp S, Huizinga TW, Kloppenburg M: Association between weight or body mass index and hand osteoarthritis: a systematic review. Ann Rheum Dis 2010, 69:761-765.

3. Teichtahl AJ, Wang Y, Wluka AE, Cicuttini FM: Obesity and knee osteoarthritis: new insights provided by body composition studies. Obesity (Silver Spring) 2008, 16:232-240.
4. Wang Y, Wluka AE, English DR, Teichtahl AJ, Giles GG, O'Sullivan R, Cicuttini FM: Body composition and knee cartilage properties in healthy, communitybased adults. Ann Rheum Dis 2007, 66:1244-1248

5. Felson DT, Zhang Y, Anthony JM, Naimark A, Anderson JJ: Weight loss reduces the risk for symptomatic knee osteoarthritis in women. The Framingham Study. Ann Intern Med 1992, 116:535-539.

6. Toda Y, Toda T, Takemura S, Wada T, Morimoto T, Ogawa R: Change in body fat, but not body weight or metabolic correlates of obesity, is related to symptomatic relief of obese patients with knee osteoarthritis after a weight control program. J Rheumatol 1998, 25:2181-2186.

7. Sowers MF, Yosef M, Jamadar D, Jacobson J, Karvonen-Gutierrez C, Jaffe M: BMI vs. body composition and radiographically defined osteoarthritis of the knee in women: a 4-year follow-up study. Osteoarthritis Cartilage 2008, 16:367-372.

8. Hochberg MC, Lethbridge-Cejku M, Plato CC, Wigley FM, Tobin JD: Factors associated with osteoarthritis of the hand in males: data from the Baltimore Longitudinal Study of Aging. Am J Epidemiol 1991, 134:1121-1127.

9. Abbate LM, Stevens J, Schwartz TA, Renner JB, Helmick CG, Jordan JM: Anthropometric measures, body composition, body fat distribution, and knee osteoarthritis in women. Obesity (Silver Spring) 2006, 14:1274-1281.

10. Holliday KL, McWilliams DF, Maciewicz RA, Muir KR, Zhang W, Doherty M: Lifetime body mass index, other anthropometric measures of obesity and risk of knee or hip osteoarthritis in the GOAL case-control study. Osteoarthritis Cartilage 2011, 19:37-43.

11. Davis MA, Neuhaus JM, Ettinger WH, Mueller WH: Body fat distribution and osteoarthritis. Am J Epidemiol 1990, 132:701-707.

12. Hochberg MC, Lethbridge-Cejku M, Scott WW Jr, Plato CC, Tobin JD: Obesity and osteoarthritis of the hands in women. Osteoarthritis Cartilage 1993, 1:129-135.

13. Kalichman L, Kobyliansky E: Age, body composition, and reproductive indices as predictors of radiographic hand osteoarthritis in Chuvashian women. Scand J Rheumatol 2007, 36:53-57.

14. Hamdy O, Porramatikul S, Al-Ozairi E: Metabolic obesity: the paradox between visceral and subcutaneous fat. Curr Diabetes Rev 2006, 2:367-373.

15. Fox CS, Massaro JM, Hoffmann U, Pou KM, Maurovich-Horvat P, Liu CY, Vasan RS, Murabito JM, Meigs JB, Cupples LA, D'Agostino RB Sr, O'Donnell CJ: Abdominal visceral and subcutaneous adipose tissue compartments: association with metabolic risk factors in the Framingham Heart Study. Circulation 2007, 116:39-48.

16. Pou KM, Massaro JM, Hoffmann U, Vasan RS, Maurovich-Horvat P, Larson MG, Keaney JF Jr, Meigs JB, Lipinska I, Kathiresan S, Murabito JM, O'Donnell CJ, Benjamin EJ, Fox CS: Visceral and subcutaneous adipose tissue volumes are cross-sectionally related to markers of inflammation and oxidative stress: the Framingham Heart Study. Circulation 2007, 116:1234-1241.

17. Pottie P, Presle N, Terlain B, Netter P, Mainard D, Berenbaum F: Obesity and osteoarthritis: more complex than predicted! Ann Rheum Dis 2006, 65:1403-1405.

18. Tilg H, Moschen AR: Adipocytokines: mediators linking adipose tissue, inflammation and immunity. Nat Rev Immunol 2006, 6:772-783.

19. Dumond H, Presle N, Terlain B, Mainard D, Loeuille D, Netter P, Pottie P: Evidence for a key role of leptin in osteoarthritis. Arthritis Rheum 2003, 48:3118-3129.

20. de Mutsert R, den Heijer M, Rabelink TJ, Smit JW, Romijn JA, Jukema JW, de RA, Cobbaert CM, Kloppenburg M, le Cessie S, Middeldorp S, Rosendaal FR: The Netherlands Epidemiology of Obesity (NEO) study: study design and data collection. Eur J Epidemiol 2013, 28:513-523.

21. Ritchie JD, Miller CK, Smiciklas-Wright H: Tanita foot-to-foot bioelectrical impedance analysis system validated in older adults. J Am Diet Assoc 2005, 105:1617-1619.

22. Altman R, Alarcon G, Appelrouth D, Bloch D, Borenstein D, Brandt K, Brown C, Cooke TD, Daniel W, Gray R, et al: The American College of Rheumatology criteria for the classification and reporting of osteoarthritis of the hand. Arthritis Rheum 1990, 33:1601-1610.

23. Korn EL, Graubard BI: Epidemiologic studies utilizing surveys: accounting for the sampling design. Am J Public Health 1991, 81:1166-1173.

24. Analysis of Complex Survey Samples. [http://www.jstatsoft.org/v09/08/paper]

25. Hoeveel mensen hebben overgewicht? [http://www.rivm.nl/nldemaat]

26. Jonsson $H$, Helgadottir GP, Aspelund T, Eiriksdottir G, Sigurdsson $S$, Ingvarsson T, Harris TB, Launer L, Gudnason V: Hand osteoarthritis in older women is associated with carotid and coronary atherosclerosis: the AGES Reykjavik study. Ann Rheum Dis 2009, 68:1696-1700. 
27. Hoeven TA, Kavousi M, Clockaerts S, Kerkhof HJ, van Meurs JB, Franco O, Hofman A, Bindels P, Witteman J, Bierma-Zeinstra S: Association of atherosclerosis with presence and progression of osteoarthritis: the Rotterdam Study. Ann Rheum Dis 2013, 72:646-651.

28. Haara MM, Manninen P, Kroger H, Arokoski JP, Karkkainen A, Knekt P, Aromaa A, Heliovaara M: Osteoarthritis of finger joints in Finns aged 30 or over: prevalence, determinants, and association with mortality. Ann Rheum Dis 2003, 62:151-158.

29. Lear SA, Humphries KH, Kohli S, Frohlich JJ, Birmingham CL, Mancini GB: Visceral adipose tissue, a potential risk factor for carotid atherosclerosis: results of the Multicultural Community Health Assessment Trial (M-CHAT). Stroke 2007, 38:2422-2429.

30. Ditomasso D, Carnethon MR, Wright CM, Allison MA: The associations between visceral fat and calcified atherosclerosis are stronger in women than men. Atherosclerosis 2010, 208:531-536

31. Indulekha K, Anjana RM, Surendar J, Mohan V: Association of visceral and subcutaneous fat with glucose intolerance, insulin resistance, adipocytokines and inflammatory markers in Asian Indians (CURES-113). Clin Biochem 2011, 44:281-287.

32. Hanley AJ, Wagenknecht LE, Norris JM, Bryer-Ash M, Chen YI, Anderson AM, Bergman R, Haffner SM: Insulin resistance, beta cell dysfunction and visceral adiposity as predictors of incident diabetes: the Insulin Resistance Atherosclerosis Study (IRAS) Family study. Diabetologia 2009, 52:2079-2086.

33. Chen TH, Chen L, Hsieh MS, Chang CP, Chou DT, Tsai SH: Evidence for a protective role for adiponectin in osteoarthritis. Biochim Biophys Acta 2006, 1762:711-718.

34. Yusuf E, loan-Facsinay A, Bijsterbosch J, Klein-Wieringa I, Kwekkeboom J, Slagboom PE, Huizinga TW, Kloppenburg M: Association between leptin, adiponectin and resistin and long-term progression of hand osteoarthritis. Ann Rheum Dis 2011, 70:1282-1284.

35. Camhi SM, Bray GA, Bouchard C, Greenway FL, Johnson WD, Newton RL, Ravussin E, Ryan DH, Smith SR, Katzmarzyk PT: The relationship of waist circumference and BMI to visceral, subcutaneous, and total body fat: sex and race differences. Obesity (Silver Spring) 2011, 19:402-408.

36. Carroll JF, Chiapa AL, Rodriquez M, Phelps DR, Cardarelli KM, Vishwanatha JK, Bae S, Cardarelli R: Visceral fat, waist circumference, and BMI: impact of race/ethnicity. Obesity (Silver Spring) 2008, 16:600-607.

37. Onat A, Ugur M, Can G, Yuksel H, Hergenc G: Visceral adipose tissue and body fat mass: predictive values for and role of gender in cardiometabolic risk among Turks. Nutrition 2010, 26:382-389.

38. Onat A, Ayhan E, Hergenc G, Can G, Barlan MM: Smoking inhibits visceral fat accumulation in Turkish women: relation of visceral fat and body fat mass to atherogenic dyslipidemia, inflammatory markers, insulin resistance, and blood pressure. Metabolism 2009, 58:963-970.

39. Onat $A$, Can G: Enhanced proinflammatory state and autoimmune activation: a breakthrough to understanding chronic diseases. Curr Pharm Des 2013 [Epub ahead of print].

40. Gagnon C, Menard J, Bourbonnais A, Ardilouze JL, Baillargeon JP, Carpentier AC, Langlois MF: Comparison of foot-to-foot and hand-to-foot bioelectrical impedance methods in a population with a wide range of body mass indices. Metab Syndr Relat Disord 2010, 8:437-441.

41. Nunez C, Gallagher D, Visser M, Pi-Sunyer FX, Wang Z, Heymsfield SB: Bioimpedance analysis: evaluation of leg-to-leg system based on pressure contact footpad electrodes. Med Sci Sports Exerc 1997, 29:524-531.

\section{Submit your next manuscript to BioMed Central and take full advantage of:}

- Convenient online submission

- Thorough peer review

- No space constraints or color figure charges

- Immediate publication on acceptance

- Inclusion in PubMed, CAS, Scopus and Google Scholar

- Research which is freely available for redistribution

Submit your manuscript at www.biomedcentral.com/submit
Ciomed Central 